\title{
プラスチックの平面応力状態の考え方を 取り入れた新しい歯ブラシの開発
}

\section{1.はじめに}

日用品としての歯ブラシは, 柄と毛といった極めて単純 な構成で成り立ち, かつ手ごろ価格な商品のためか, その 材料や構造について理論的に掘り下げられた研究はほとん ど報告されていない.

我々は，材料が平面歪状態から平面応力状態に移行する と，大きく曲がっても折れにくくなるという現象に着目し， $\mathrm{PP}$ 樹脂の射出成形品を作製して力学特性を検討した。そ の結果，一定の厚み水準以下では，大きな応力が加わって も破断は発生せず，折れにくくなるという事実を確認した. この知見を基に予期せぬ過剩な負荷が加わった際にも破断 せず，高度な安全性が確保できるこども用歯ブラシを開発 したので，一部の実験データと合わせて以下に紹介する。

\section{2. 実験方法}

(1)材料：汎用 PP 樹脂 3 種 (MFR $8,15 ， 45$ ( $\mathrm{g} / 10$ 分))

(2)試験片：幅 $5 \mathrm{~mm}$, 長さ $100 \mathrm{~mm}$, 厚さ $0.5,1,2,3,5$ $\mathrm{mm}$ の射出成型体.

(3)試験方法：IZOD 衝撃試験（JIS K 7110 を参考） 曲げ弾性率試験（JIS K 7171 を参考）

\section{3 . 結果}

実験には，先ず PP 樹脂 3 種類の厚さ 4 水準 $(0.5,1$, $3,5 \mathrm{~mm}$ ）の成型品を試験片として用いた. IZOD 試験 の結果, 厚さ $3 \mathrm{~mm}$ 以上の試験片には, 白化もしくは破断 が確認された。一方, $1 \mathrm{~mm}$ 以下の試験片には外観上の変 化が観察されなかった. また MFRの違いによる明瞭な差 は確認されなかったが，曲げ弾性率が高く厚い試験片は破 断することが判明した。

次に厚さ $2 \mathrm{~mm}$ を追加し, 3 水準 $(1,2,3 \mathrm{~mm})$ の試 験片を新たに成型して同様の実験を行なった。この結果， 厚さ $3 \mathrm{~mm}$ の試験片は前述の実験結果と同じ白化が再現 (図 1) されたが，2 $\mathrm{mm}$ 以下の試験片には外観上の変化が 観察されなかった。すなわち本実験に用いた PP 樹脂の射

表 1 追加実験結果

\begin{tabular}{l|c|c|c|c|c|c|c|c|c|c}
\hline MFR & \multicolumn{5}{|c|}{8} & \multicolumn{3}{|c|}{15} & \multicolumn{5}{|c}{45} \\
\hline 板厚 & $1 \mathrm{~mm}$ & $2 \mathrm{~mm}$ & $3 \mathrm{~mm}$ & $1 \mathrm{~mm}$ & $2 \mathrm{~mm}$ & $3 \mathrm{~mm}$ & $1 \mathrm{~mm}$ & $2 \mathrm{~mm}$ & $3 \mathrm{~mm}$ & $5 \mathrm{~mm}($ 参 $)$ \\
\hline 曲げ弾性率 $(\mathrm{MPa})$ & 863 & 1380 & 1370 & 894 & 1403 & 1397 & 1081 & 1576 & 1574 & 1877 \\
\hline IZOD $(\mathrm{J})$ & $\mathrm{NB}$ & $\mathrm{NB}$ & $\mathrm{NB}$ & $\mathrm{NB}$ & $\mathrm{NB}$ & $\mathrm{NB}$ & $\mathrm{NB}$ & $\mathrm{NB}$ & $0.49 \%$ & 1.0 \\
\hline IZOD 後の外観 & 変化なし & 変化なし & 白化 & 変化なし & 変化なし & 白化 & 変化なし 変化なし & 白化 & 破断 \\
\hline
\end{tabular}

※2 本破断の平均,曲げ弾性率試験:島津製作所 AGS-X C.H.S.2 mm/min n=5, IZOD 試験：東洋精機 DG-1 B 秤量 $2.75 \mathrm{~J} \mathrm{n=10}$

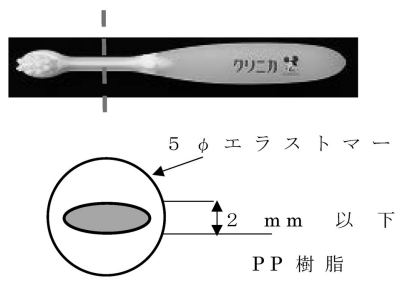

図 2 首部断面略図

我々は実験データをもとに,歯ブラシの最も細い部位 (通 称首部) が，平面応力状態となるための構造を設定 (図 2 : 首部断面略図）し，更に全周をなだらかな曲線になるよう にエラストマーにて被覆した柔軟性の高いこども専用の歯 ブラシ（図 3）を開発した.

この歯ブラシの首部は，PP 樹脂への局所的な応力集中 を避けるため，長楕円形状とし，確実な平面応力状態とす るため短軸直径は $2 \mathrm{~mm}$ 以下に設定した。歯ブラシに突発 的な過剩な負荷が加わった場合，平面応力状態にある首部 が破断することなく変形して，人体への被害を大幅に低減 させる点が最大の特長である。

紙面の都合上実験内容の一 部のデーターのみを記載した が，詳細は，プラスチック成 型加工学会第 28 回年次大会 にて発表する予定である。

歯ブラシを口に入れたまま, 走る，遊ぶ等をしないよう保 護者の方はご注意いただいた 上で，理論に螤付けられた新 しい製品を，是非多くのお客 様にお試しいただきたい。

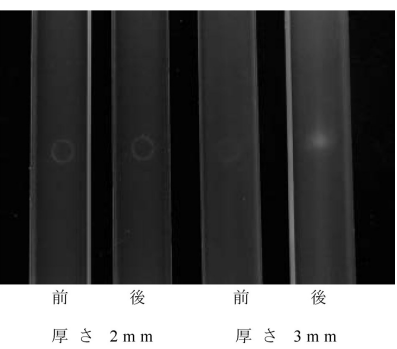

図 1 IZOD 試験前後の 試験片（MFR 8） （右端の試験片のみ中 央に白化が確認できる)

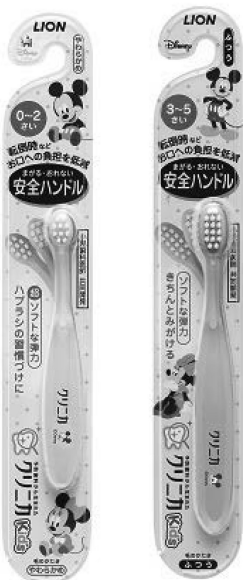

図 3 新製品
〈問合せ先〉

ライオン(秼) 研究開発本部 オーラルケア研究所 小林利彰

東京都江戸川区平井 7-2-1（于132-0035）

TEL. (03) 3616-4486

FAX. (03) 3616-5376
* Kobayashi, Toshiaki

ライオン(株) 研究開発本部 オーラルケア研究所 東京都江戸川区平井 7-2-1（テ132-0035）

Kobatosi@lion.co.jp

2016.11. 1 受理 